Јелена Љ. Спасић

Универзитет у Крагујевцу

Факултет педагошких наука у Јагодини

Катедра за филолошке науке
УДК 811.163.41'232-053.4

https://doi.org/10.18485/uzdanica.2020.17.1.10

Оригинални научни рад

Примљен: 20. јануар 2020.

Прихваћен: 9. март 2020.

\title{
ЛЕКСИЧКИ РАЗВОЈ ДЕТЕТА ПРЕДШКОЛСКОГ УЗРАСТА $^{1}$
}

$A \bar{u} c \bar{u} p a \kappa \bar{u}:$ Дечији лексички развој у предшколском узрасту предмет је проучавања великог броја студија у свету и код нас, у новије време најчешће са аспекта когнитивне лингвистике и психолингвистике. Преглед доступне литературе указује на значај језичког и социјалног окружења као подстицаја лексичког развоја деце, као и на повезаност лексичког и синтаксичког развоја, али и повезаност фонолошке свести и осећаја за риму са разумевањем речи и говорном продукцијом. Указујемо на неопходност праћења лексичког развоја деце, из чега происходе веће могућности за планирање лексичких и семантичких игара, као и за проширивање дечије језичке игре према принципима уоченим приликом грађења дечијих неологизама и према принципима усвајања значења речи. Рад на лексичком развоју деце предшколског узраста треба усмерити не само на богаћење речника у смислу повећања броја речи, већ и на освешћивање полисемије, хомонимије, синонимије и антонимије.

Кључне речи: усвајање језика, лексички развој, српски језик, предшколски узраст.

1. Кристал разликује усвајање језика, као усвајање лингвистичких законитости у области граматике, фонологије или семантике, од развоја говора, под којим подразумева примену усвојених правила кроз велики број језичких и друштвених интеракција (Кристал 1985: 5). Усвајање матерњег језика код деце с успореним језичким развојем често почиње или се значајно убрзава поласком детета у вртић, јер богато језичко и социјално окружење подстиче развој говора (Салим, Мехавеш 2014: 23). С порастом броја језичких интеракција у којима дете активно учествује, долази до убрзаног лексичког и синтаксичког развоја.

Језички богате интеракције у којима дете учествује током прве три године живота, њихов квалитет и квантитет, као и заједничко читање, један су

\footnotetext{
${ }^{1}$ Реализацију овог истраживања финансирало је Министарство просвете, науке и технолошког развоја Републике Србије (бр. уговора 451-03-68/2020-14/ 200140).
} 
од најбитнијих подстицаја дечијег лексичког развоја, а осим броја речи утичу на лексичку разноликост, морфолошку сложеност, стварање нових речи, па посредно утичу и на каснија школска постигнућа (Заухе и др. 2016: 319). Праћење лексичког развоја деце, као и укупног језичког развоја, изузетно је значајно, јер је ниво лексичког развоја један од значајнијих предиктора академског постигнућа и социјалних вештина (Глигоровић, Буха, Доброта-Давидовић 2018: 12).

2.1. Лексички развој говора детета није могуће посматрати изоловано, без узимања у обзир целокупног језичког развоја. Чак и појава прве речи у говору детета може се посматрати као почетак синтаксичког развоја (Стакић 2017: 33). Прве речи су холофразе и у 60\% случајева у питању су речи именовања, а у 20\% случајева исказују радњу (Чабаркапа и др. 2007: 175). Појава прве речи се најчешће везује за период од 12. до 18. месеца, ређе пре првог рођендана, а може се јавити и знатно касније, око трећег рођендана. Дете реч прима као глобални аудитивни утисак и на почетку лексичког развоја оно понавља оно што је чуло уз бројне метатезе и омисије (Радуловић 2017: 114-115). Разумевање значења појединачних речи веома је значајно за разумевање континуираног говора код четворогодишњака (Глигоровић, Буха, Доброта-Давидовић 2018: 15). Препознавање и продукција риме уз визуелну подршку значајно корелира с другим аспектима разумевања говора, нарочито с разумевањем речи (Глигоровић, Буха, Доброта-Давидовић 2018: 16). Шестогодишњаци препознају око две риме од задатих десет, док су седмогодишњаци и осмогодишњаци знатно успешнији у препознавању риме (Глигоровић, Буха, Доброта-Давидовић 2018: 19).

Језичке способности јасније указују на развијеније интелектуалне способности него неки други аспекти когнитивне процене, а разумевање говора претходи могућности говорне продукције (Глигоровић, Буха, Доброта-Давидовић 2018: 10). Развој говора предшколског детета одвија се кроз неколико фаза, најпре кроз развој лексикона, потом кроз употребу речи у значењу реченице, док у каснијим фазама лексички и синтаксички развој теку упоредо. Током прве фазе лексичког развоја у говору детета се јављају именице, стереотипни придеви, прилози временског односа за прошле радње, глаголи или изрази за дозивање. Другу фазу карактерише појава холофразе, односно појава реченице од две речи (глагол и објекат, субјекат и објекат, именица и придев или прилог), честе елизије, инверзије, без употребе предлога. У трећој фази се развија синтакса реченице, јер се развија правилна реченична структура (субјекат, предикат, објекат), дете користи будуће и прошло време; предлоге $\kappa a, o g, c a$, за, правилно употребљава заменице, а присутни су и бројни елиптични изрази. Четврту фазу карактеришу појава односних и временских реченица, појава показних заменица и придева, употреба прилога и везника (Малрије 1981: 218-220). Приликом усвајања било ког језика као матерњег, развоју морфологије претходи фаза у којој дете користи 
ономатопеје и нетипичне форме деминутива, речи добијене редупликацијом ономатопеја или скраћењем (Попова, Попов 2013: 378). Разумевање првих речи повезаних с контекстом почиње између осмог и десетог месеца, а до навршених дванаест месеци дете препознаје познате речи и ван контекста (Глигоровић, Буха, Доброта-Давидовић 2018: 11). Експресивни фонд речи се у периоду између друге и шесте године богати за 500-600 речи (Голубовић 1997: 57). Новија истраживања показују да број речи у дечијем лексикону са навршене три године значајно утиче на способност читања у млађим разредима основне школе, што је један од важних предиктора каснијег успеха у школовању (Заухе и др. 2016: 319). Такође, успешност препознавања риме корелира с разумевањем речи. Способност препознавања риме зависи од нивоа фонолошке свесности, која је уједно и снажан предиктор и корелат тешкоћа у читању, али и проблема с разумевањем речи (Глигоровић, Буха, Доброта-Давидовић 2018: 19), јер деца лакше разумеју оне речи које знају да изговоре, а доказан је и утицај правилне артикулације на богат активни речник (Чабаркапа и др. 2003: 112-117).

Анализа усвајања предлога код деце која су говорници српског језика показала је да је фреквентност појединих предлога у говору деце, као што је предлог $\kappa o g$, условљена честим јављањем одређеног предлога у говору одраслих, док на ређу употребу појединих предлога утиче вишеструкост значења која се њиме могу исказати (као код предлога $c / c a$ ) (Савић, Анђелковић 2004: 445). Наведена студија указује на механизам усвајања значења речи. Деца у раној фази језичког развоја разумеју само неке од компоненти значења речи које чују у говору одраслих, потом кроз употребу предлога са именицама проширују своје знање о значењу предлога кроз различите синтаксичке и семантичке контексте, да би на узрасту од шест година усвојила семантику предлога и почела да их користе на исти начин као и одрасли (Савић, Анђелковић 2004: 446). Иако је учесталост одређене речи у говору одраслих упућеном детету кључни фактор за усвајање лексике, концептуална и структурна сложеност одређене речи може условити њено касније усвајање (Савић, Анђелковић 2004: 445).

Старији предшколски период се сматра интуитивним језичким периодом. Након што је до пете године дете усвојило матерњи језик у довољној мери да може да комуницира, од шесте до четрнаесте године оно још увек развија велики број језичких вештина. Када је реч о лексичком развоју, интуитивни језички период карактерише дечија креативност у тумачењу значења речи, а такве лексичке иновације могу се појављивати чак и у адолесценцији (Луст 2006: 229).

2.2. Један од начина праћења дечијег лексичког развоја јесте и бележење карактеристичних појава у говору у дечијем лексикону, односно бележење дечијих неологизама. Забележене а необјављене форме дечијег говорног стваралаштва припремају стваралачку оригиналност, а бесциљна језичка 
комика и необуздана спонтана говорна игра дају одушка говорној машти (Бахтин 1978: 439). М. Кебара проучава дечије неологизме у светлу лингвокогнитивне и психолингвистичке парадигме, као прецедент поетске употребе речи (Кебара 2014: 109-125), односно у функцији прецедента језичке игре (Кебара 2017: 315-331), истичући да, иако најчешће настају деривацијом према готовим творбеним моделима, дечији неологизми представљају вид језичке игре у којој је спољашња (морфолошка) форма речи подређена унутрашњем значењу, које проистиче из дечијег мишљења (Кебара 2018: 184). Граматичка транспозиција, која често лежи у подлози дечијих неологизама, проучавана је у функцији поступка грађења језичке игре и израза језичке личности детета кроз стварање неосвешћених или освешћених лексичких творевина на основу постојеће когнитивне базе српских творбених модела (Кебара 2018: 183).

Морфолошки аспект дечијих неологизама предмет је проучавања новије студије дневничког типа, која показује да у млађем предшколском узрасту поигравање с морфолошком формом из ког настаје дечији неологизам происходи из несвесне језичке игре, док у је у старијем узрасту при стварању дечијих неологизама присутна свесна интенција при трансформисању морфолошке форме речи (Спасић, Ђуровић 2020, у штампи). Развој дечијег говора је повезан с развојем памћења, развојем аудитивне дискриминације, али и изражавањем емоција и симболичком игром (Бланк 1974: 244). Када говоримо о лексичком развоју деце, управо се кроз појаву дечијих неологизама очитује веза између изградње фонемске свести, изражавања емоција и језичке игре. Не само да су дечији неологизми прецедент језичке игре, већ се кроз различите језичке игре може подстаћи дечија склоност ка грађењу дечијих неологизама и тако поспешити лексички развој деце. Поред дечијих неологизама, у појаве карактеристичне за лексички развој деце спадају генерализација (проширивање значења једне речи) и рестрикција (сужавање значења речи, нпр. коришћење назива за род за одређену врсту животиње). Током лексичког развоја фазу претеране генерализације замењује фаза рестрикције (Стакић 2017: 36).

Када је реч о интеракцији пола и узраста у домену лексичког развоја деце, истраживања показују да девојчице имају богатији рецептивни речник у раном предшколском узрасту, између пете и десете године полне разлике нестају, док након десете године дечаци показују незнатно боље резултате у препознавању речи (Глигоровић, Буха, Доброта-Давидовић 2018: 23).

Став који родитељи имају према матерњем језику и изложеност детета богатим језичким интеракцијама код куће представља основу за усвајање матерњег језика, а усвајање матерњег језика јесте предуслов за учење страних језика (Милошевић 2016: 184). Иако су родитељи најважнији говорни модел детета, изузетно је важна и улога васпитача у предшколским установама, а њихови константни подстицаји лексичком развоју деце кроз богате језичке 
интеракције, заједничко читање и језичке игре поспешују процесе анализе и синтезе речи кроз које деца откривају структуру и семантику речи.

Као што се лексичко богатство једног језика не мери бројем речи у његовом лексикону, већ могућношћу да се адекватније изразе мисли и осећања људи у датом друштву (Вукићевић 2017: 74), тако се ни проучавање лексичког развоја деце не може свести на пребројавање речи у говору деце, већ се у обзир мора узети и развој значења речи, као и развој односа међу речима, као што су полисемија, хомонимија, синонимија и антонимија.

2.3. Било да је реч о деци уредног говорно-језичког развоја или о деци која мало или слабо говоре, рад на развоју говора треба организовати превасходно кроз игру, укључујући лексичке и семантичке вежбе, а исти поступак се користи и при рехабилитацији глуве и наглуве деце (Соколовац и др. 2015: 439).

Фигуре звука подстичу не само бољи изговор гласова кроз асонанцу и алитерацију, већ кроз ономатопејске речи, погодне за рад с децом средњег и старијег предшколског узраста, богате дечији речник (Столић, Муратовић Дробац 2017: 107).

Како бисмо подстакли коришћење сложеница у дечијем говору, користимо лексичку игру грађења сложеница, при чијем осмишљавању водимо рачуна о неколико критеријума, а то су граматички критеријум, критеријум разумљивости сложеница, критеријум тематске примерености, критеријум очигледне представљивости, критеријум фреквенције и критеријум васпитне примерености (Мићић, Вукомановић Растегорац 2016: 197-199). Такође, од деце можемо тражити да аналогијом граде сложенице према истом творбеном моделу као у низу сложеница које смо понудили као модел, за почетак са истим другим формантом у сваком сложеничком споју, уз интеграцију покрета, илустрације сложенице и изговорене речи за сваки од примера.2

Такође, филм се користи као подстрек богаћења речника ученика првог разреда основне школе, кроз интегрисану наставу, кроз опис боја, облика и музике у цртаном филму, проналажење изведених речи и грађење нових презимена за ликове у цртаном филму (Тодоров, Сокић 2018: 186), а исти модел би се могао применити и у припремној предшколској групи, кроз интеграцију садржаја из различитих области васпитно-образовног рада са циљем поспешивања лексичког развоја деце. Рад на развоју медијске културе предшколске деце, али и едукација васпитача и родитеља у погледу сврсисходног коришћења медија као што су цртани филмови, видео-игре и интернет, могао би умањити негативан утицај који претерана изложеност медијским садржајима има на развој дечијег говора. Пратећи лексички развој деце, васпитачи уочавају честу употребу страних речи код деце која су превише изложена медијским садржајима (Сретеновић 2014: 171). Медијски садржаји могу

${ }^{2}$ Примера ради, деци кажемо: „Ако кишобран брани од кише, сунцобран брани од сунца, од чега брани блатобран? Од чега брани ветробран? Од чега брани падобран?” 
бити подстицајни за лексички развој деце ако су пажљиво одабрани према критеријуму узраста, временски ограничени и ако родитељ/васпитач прати медијски садржај са дететом, коментарише, тумачи медијску поруку, објашњава непознате речи и проверава дечији доживљај виђеног.

3. С обзиром на повезаност лексичког развоја деце с другим аспектима развоја говора, није довољно богатити речник предшколског детета кроз упознавање с књижевним делима. Поред разноврсних лексичких и семантичких вежбања у форми игре, уз визуелну подршку, од најранијег предшколског узраста треба радити на развоју фонолошке свесности, користити у раду игре риме, а у старијем предшколском узрасту вежбати грађење и препознавање риме, пружајући притом подршку и развоју метајезичке свести. Интеракција наведених аспеката развоја говора води бржем лексичком развоју, али и разумевању континуираног говора, као и успешнијем читању и писању. Рад на лексичком развоју говора деце предшколског узраста уз подршку свим другим аспектима језичког развоја са којима он корелира на тај начин поспешује будуће академске вештине детета.

\section{ЛИТЕРАТУРА}

Бахтин (1978): Михаил Бахтин, Сйваралашӣво Франсоа Раблеа и нароgна кулйура среgњеїа века и ренесансе, Београд: Нолит.

Битнер, Рулиг (2013): Dagmar Bittner, Nadja Ruhlig, Lexical Bootstrapping: The Role of Lexis and Semantics in Child Language Development, Berlin: De Gruyter Mouton. Retrieved from http://search.ebscohost.com/login.aspx?direct=true\&db=e000xww\&AN= 604279\&site=eds-live

Бланк (1974): Marion Blank, Cognitive Functions of Language in the Preschool Years, Developmental Psychology, Vol. 10, No. 2, US: American Psychological Association, 229-245.

Васић (2009): Смиљка Васић, Тест - речник за децу од 3 до 7 година, У: В. Милатовић (ур.), Мейоgика развоја іовора: избор научних и сииручних раgова за

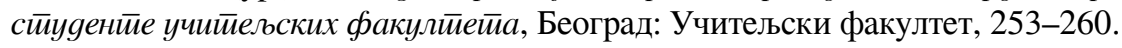

Вукићевић (2017): Наташа Вукићевић, Социолошки аспекти језичке културе,

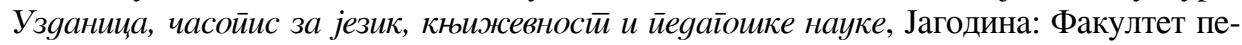
дагошких наука, XIV/1, 61-78.

Глигоровић, Буха, Доброта-Давидовић (2018): Милица Глигоровић, Наташа Буха, Нада Доброта-Давидовић, Разумевање говора код деце од шест до девет година, Сйецијална еgукација и рехабилитиација, Вол. 17, бр. 1, 9-31.

Голубовић (1997): Славица Голубовић, Клиничка лойойеgија I, Београд: Дефектолошки факултет, Биг штампа.

Заухе, Тул, Махони, Стејпел-Вакс (2016): Lauren Head Zauche, Taylor A. Thul, Ashley E. Darcy Mahoney, Jennifer L. Stapel-Wax, Review: Influence of Language Nutrition on Children's Language and Cognitive Development: An Integrated Review, Early Childhood Research Quarterly, 36 (July): 318-33. doi:10.1016/j.ecresq.2016.01.015. 
Кебара (2014): Марина Кебара, Језичка игра у дечјем дискурсу као прецедент

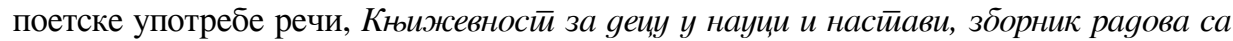
научноі скуйа (Јагодина, 11-12. април 2014), 109-125.

Кебара (2017): Марина Кебара, Семантизација спонтаних деривата (дечијих неологизама) у функцији прецедентности језичке игре, Срйски језик, 22, Београд: Научно друштво за неговање и проучавање српског језика, 315-331.

Кебара (2018): Граматичка транспозиција у деривацији неологизама у дечјој језичкој игри, Узданииа, часойис за језик, књижевносй и иееgайошке науке, XV/1, Јагодина: Факултет педагошких наука, 165-186.

Кристал (1985): David Crystal, A Dictionary of Linguistics and Phonetics, Oxford: Basil Blackwell.

Луст (2006): Barbara Lust, Child Language : Acquisition and Growth, Cambridge: Cambridge University Press.

Малрије (1981): Филип Малрије, Психолошки асйекӣи формирања реченице коg gейей $а$, Београд: Завод за уџбенике и наставна средства.

Милошевић (2016): Olja Milošević, Parent's Perspectives on Their Children's Lan-

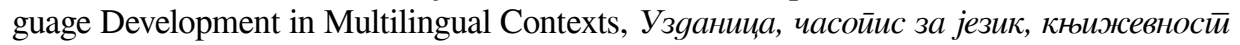
и йеgаїошке науке, XIII/2, Јагодина: Факултет педагошких наука, 177-187.

Мићић, Вукомановић Растегорац (2016): Вишња Мићић, Владимир Вукомановић Растегорац, Како настају речи: игролики приступ творби речи у предшколској установи, У: Савремено йреgшколско васиийање и образовање: изазови и дилеме, Јагодина: Факултет педагошких наука, 195-208.

Попова, Попов (2013): Velka Popova, Dimitar Popov, Two Bulgarian children in the dawn of morphological ontogenesis, The 1st International Global Virtual Conference, 378-383.

Радуловић (2017): Милица Радуловић, Усвајање српског као матерњег језика,

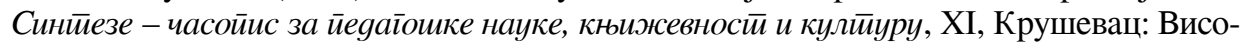
ка школа струковних студија за васпитаче, 109-122.

Савић, Анђелковић (2004): Маја Савић, Даринка Анђелковић, The Acquisition of Prepositions in Serbian: Factors and Mechanisms of Development, Психолоїија, иасойис Друшйва йсихолоїа СР Србије, 37, бр. 4 (2004), 415-450.

Салим, Мехавеш (2014): Jamal Azmi Salim, Momammad Mehawesh, Stages in Language Acquisition: A Case Study, English Language and Literature Studies, Vol. 4, No. 4, 16-24.

Соколовац, Славнић, Шкрбић, Лемајић-Комазец (2015): Ивана Соколовац, Светлана Славнић, Рената Шкрбић, Слободанка Лемајић-Комазец, Продукција основних глаголских времена код деце са кохлеарним имплантом, Сйецијална еgyкација и рехабилийација, XV/4, Београд: Факултет за специјалну едукацију и рехабилитацију, 437-458.

Спасић, Ђуровић (2020): Јелена Спасић, Сања Ђуровић, Морфолошки и твор-

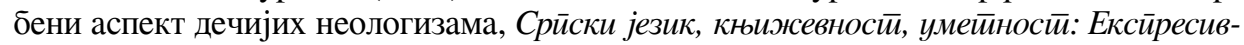

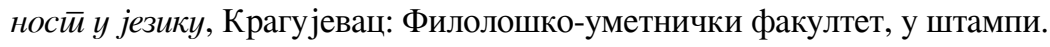

Сретеновић (2014): Далиборка Сретеновић, Утицај медија на развој говора предшколског детета, Зборник ВШССОВ, IX/2, Кикинда: Висока школа струковних студија за образовање васпитача, 163-176. 
Стакић (2017): Мирјана Стакић, Усвајање значења речи у почетним фазама

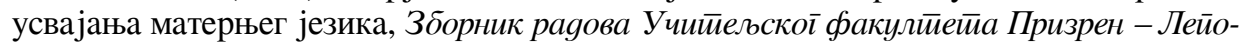
савић, XI, Лепосавић: Учитељски факултет, 31-40.

Столић, Муратовић Дробац (2017): Даница Столић, Весна Муратовић Дробац,

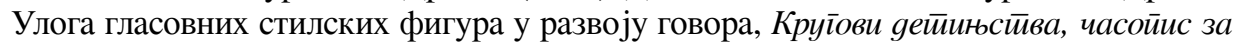

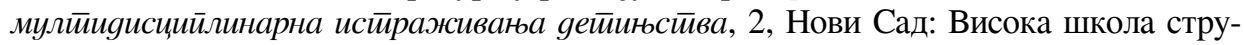
ковних студија за образовање васпитача, 104-112.

Тодоров, Сокић (2018): Нада Тодоров, Оља Сокић, Филм у функцији богаћења речника ученика од првог до четвртог разреда основне школе, Узgаница, часойис

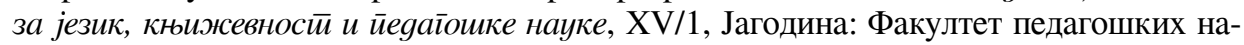
ука, 187-205.

Чабаркапа, Вуковић, Костић, Пунишић (2003): Наташа Чабаркапа, Миле Вуковић, Маја Костић, Силвана Пунишић, Однос развијености артикулације и нивоа лексикона код деце, У: М. Совиљ (ур.), Говор и језик, Београд: Институт за експерименталну фонетику и патологију говора, 112-117.

Чабаркапа, Пунишић, Суботић, Човић (2007): Наташа Чабаркапа, Силвана Пунишић, Мишко Суботић, Бранислава Човић, Синтаксичка комплексност говорно језичке развијености деце предшколског узраста, Зборник раgова 50. конференције за ЕТРАН, Београд, том II, 458-461.

\author{
Jelena Lj. Spasić \\ University of Kragujevac \\ Faculty of Education in Jagodina \\ Department for Philology
}

\title{
LEXICAL DEVELOPMENT OF A PRESCHOOL CHILD
}

Summary: The paper reviews recent studies on children's lexical development and points to the importance of examining child language and supporting different aspects of language acquisition which are related to the lexical development. The examination of the lexical development of a preschool child should include semantical aspect as well. The research should not be done by simply counting the words in children lexicon; in addition to this, the acquisition of semantic dimension of words, children's understanding of words and their ability to produce neologisms should be taken into consideration. There is a strong connection between children's ability to make and recognise a rhyme, their phonological and metalinguistic awareness on the one hand, and faster lexical development, which is important predictor of reading and writting skills on the other.

Keywords: language acquisition, lexical development, Serbian language, preschool children. 